\title{
Investigasi Teoretis Interaksi Nonkovalen antara $\beta$-Siklodekstrin dan Hidroksiklorokuin
}

\author{
Ivansyah, A.L. ${ }^{1,2, *}$ \\ ${ }^{1}$ Program Studi Magister Sains Komputasi, Fakultas Matematika dan Ilmu Pengetahuan Alam, \\ Institut Teknologi Bandung, Jalan Ganesha No. 10, Bandung, Jawa Barat, 40132 \\ ${ }^{2}$ Kelompok Keahlian Kimia Analitik, Departemen Kimia, Institut Teknologi Bandung, Jalan \\ Ganesha No. 10, Bandung, Jawa Barat, 40132 \\ *alamat email korespondensi : atthar@compscience.itb.ac.id
}

\begin{abstract}
There was an outbreak with symptoms similar to SARS caused by the SARS-CoV-2 virus in the People's Republic of China at the end of 2019. The rapid spread of the virus, even in Indonesia, led to a pandemic status being given by the WHO. The use of current medications before a vaccine is identified and ready for help is one alternative to reducing COVID-19 patients. As a candidate for anti-COVID-19 drugs, Hydroxychloroquine has been extensively studied and has now reached the clinical trial stage. Hydroxychloroquine's solubility in water, however, is so limited that it affects its low human body bioavailability. The development of a stable inclusion complex with $\beta$ cyclodextrin is one way to increase Hydroxychloroquine's solubility in water. This research investigated the interaction between $\beta$-cyclodextrin and Hydroxychloroquine through molecular docking analysis and a semiempirical quantum process. The results of the semiempirical quantum method and the study of molecular docking suggest that $\beta$ cyclodextrin and Hydroxychloroquine are a stable inclusion complex. Hydroxychloroquine's solubility in aqueous solution can also be increased by forming an inclusion complex with $\beta$-cyclodextrin.
\end{abstract}

Keywords: $\beta$-Cyclodextrin; Hydroxychloroquine; SARS-CoV-2; COVID-19; Inclusion Complex

\begin{abstract}
Abstrak
Terjadi wabah dengan gejala mirip SARS yang disebabkan oleh virus SARS-CoV-2 di Republik Rakyat China pada akhir tahun 2019. Cepatnya penyebaran virus, bahkan di Indonesia, menyebabkan status pandemi diberikan oleh WHO. Penggunaan obat-obatan terkini sebelum vaksin siap digunakan merupakan salah satu alternatif untuk mengurangi jumlah pasien COVID-19. Sebagai kandidat obat anti COVID-19, hidroksiklorokuin telah dipelajari secara ekstensif dan kini telah mencapai tahap uji klinis. Kelarutan hidroksiklorokuin dalam air relatif sangat kecil sehingga bioavailabilitasnya pada tubuh manusia juga rendah. Pengembangan kompleks inklusi yang stabil dengan $\beta$-siklodekstrin merupakan salah satu cara untuk meningkatkan kelarutan hidroksiklorokuin dalam air. Penelitian ini menginvestigasi interaksi antara $\beta$-siklodekstrin dan hidroksiklorokuin secara teoretis dengan metode penambatan molekul dan kuantum semiempirik. Hasil dari metode penambatan molekul dan kuantum semiempirik memperlihatkan bahwa $\beta$-siklodekstrin dan hidroksiklorokuin membentuk kompleks inklusi
\end{abstract}


yang stabil. Kelarutan hidroksiklorokuin dalam air juga dapat ditingkatkan dengan membentuk kompleks inklusi dengan $\beta$-siklodekstrin.

Kata Kunci : $\beta$-Siklodekstrin; Hidroksiklorokuin; SARS-CoV-2; COVID-19; Kompleks Inklusi

\section{Pendahuluan}

Di RRC telah terjadi wabah dengan gejala yang mirip dengan SARS yang dipicu oleh virus SARS-CoV-2 pada akhir tahun 2019. Maraknya penyebaran virus tersebut, bahkan di Indonesia, mendorong status pandemi ditetapkan oleh WHO. Namun hingga saat ini vaksin yang telah teridentifikasi tersebut baru dalam proses penelitian sehingga belum dapat digunakan oleh manusia secara aman. Dikhawatirkan jumlah penderita COVID-19 akan bertambah jika kita menunggu vaksin tersebut sampai dapat digunakan dengan aman. Oleh karena itu, alternatif pengganti vaksin ini harus ditemukan.

Sebagai kandidat obat anti COVID-19, hidroksiklorokuin telah dipelajari secara ekstensif dan kini telah mencapai tahap uji klinis. Namun, penggunaan hidroksiklorokuin sebagai anti COVID-19 kurang efektif dan memiliki efek samping. Salah satu faktor penyebabnya adalah kelarutan hidroksiklorokuin di dalam air yang rendah sehingga bioavailabilitasnya di dalam tubuh manusia juga rendah. Pembentukan kompleks inklusi yang stabil dengan senyawa supramolekul merupakan salah satu cara untuk meningkatkan kelarutan hidroksiklorokuin dalam air. Salah satu supramolekul yang dapat digunakan adalah $\beta$-siklodekstrin.

$\beta$-siklodekstrin adalah senyawa organik siklik (oligosakarida siklik) yang diikat oleh ikatan alfa-1,4-glikosidik dengan tujuh unit glukosa. Karena kemampuannya untuk membentuk kompleks inklusi dengan molekul besar [1-3], $\beta$-siklodekstrin biasanya digunakan untuk banyak aplikasi, salah satunya adalah aplikasi medis. Banyak peneliti telah menggunakan $\beta$-siklodekstrin dalam aplikasi biomedis, seperti, meningkatkan kelarutan dan stabilitas obat [5], meningkatkan penyerapan obat, [6] menutupi bau dan rasa [7], regulasi pelepasan obat [8], menurunkan toksisitas lokal dan sistemik [9], dan peningkatan permeabilitas obat melalui hambatan sistem biologis [10].

Selain itu, penggunaan $\beta$-siklodekstrin pada kompleks inklusi dengan obat antivirus, dapat meningkatkan kinerja obat antivirus tersebut. Grancher dkk. berhasil 
Ivansyah, dkk. Akta Kimia Indonesia 5(2), 2020, 127-140

meningkatkan aktivitas antivirus ribavirin dengan membuat kompleks inklusi antara ribavirin dan $\beta$-siklodekstrin [11]. Untuk meningkatkan aktivitas antivirus gansiklovir [12], Finance dkk. telah mensintesis kompleks inklusi gansiklovir dengan $\beta$ siklodekstrin. Carrouel dkk., dalam sebuah jurnal baru-baru ini, telah berhasil mengkombinasikan obat kumur (yang mengandung citrox) dengan $\beta$-siklodekstrin untuk meminimalkan pengiriman saliva SARS-CoV-2 [13]. Namun, sejauh ini belum ada peneliti yang menyelidiki potensi $\beta$ cyclodextrin sebagai bahan untuk mengantarkan obat antivirus COVID-19, khususnya hidroksiklorokuin. Interaksi antara $\beta$-siklodekstrin dan hidroksiklorokuin akan dianalisis dalam penelitian ini dengan menggunakan metode penambatan molekul dan kuantum semiempirik.

\section{Metode Penelitian}

Penelitian ini adalah kajian teoretis menggunakan metode penambatan molekul dan semiempirik kuantum untuk mempelajari interaksi antar molekul pada kompleks inklusi $\beta$-siklodekstrin dan hidroksiklorokuin di kondisi vakum dan dalam pelarut air, yang mana berimplikasi pada kelarutan kompleks inklusi tersebut di dalam air.

Dalam penelitian ini, perangkat lunak yang digunakan antara lain : Avogadro versi 1.2.0 [14], YASARA Structure versi 20.8.23 [15], dan Gaussian 09 Rev. D.01 [16]; sedangkan Perangkat keras yang digunakan dalam penelitian ini adalah server komputer dengan spesifikasi prosessor Intel Xeon E52620 v2 @ 2.10GHz dengan total inti sebanyak 24 buah, RAM 64 GB, dan HDD 500 GB.

Kami menggunakan pendekatan komputasi yang dibagi menjadi tiga bagian dalam penelitian ini. Pendekatan komputasi yang digunakan dalam penelitian ini adalah metode komputasi yang telah digunakan pada penelitian sebelumnya [17-21]. Pertama, membuat molekul host dan molekul guest; kedua, pemodelan penambatan molekul; dan ketiga, perhitungan kuantum semiempirik PM3. Molekul host dan guest yang digunakan dalam penelitian ini adalah $\beta$-siklodekstrin dan hidroksiklorokuin. $\beta$-siklodekstrin diperoleh dari database kristalografi ccdc.cam.ac.uk dengan kode BUVSEQ02 $[22,23]$. Model dengan kode ini telah digunakan pada beberapa penelitian sebelumnya [24], [25], [26], [27], [28], [29]. 
Ivansyah, dkk. Akta Kimia Indonesia 5(2), 2020, 127-140

File mol hidroksiklorokuin diambil dari database obat di drugbank.ca [30]. Penambatan molekul dilakukan dengan menggunakan Autodock VINA yang disatukan di dalam paket perangkat lunak YASARA Structure versi 20.8.23, yang diotomatisasi dengan bantuan file makro yang diotomatiskan dengan file makro dock_run [15]. Selanjutnya, kompleks inklusi dengan energi ikat antarmolekul tertinggi, hasil dari penambatan molekul dioptimasi lebih lanjut dengan menggunakan metode kuantum semiempirik untuk memperbaiki nilai energi ikat antarmolekul agar lebih akurat. Nilai energi ikat antarmolekul hasil perhitungan kuantum semiempirik ini dihitung dengan mengikuti persamaan (1).

$$
\begin{aligned}
& \Delta E=E_{\text {optimized inclusion complex }}- \\
& \left(E_{\text {optimized host }}+E_{\text {optimized guest }}\right)
\end{aligned}
$$

dimana $E_{\text {optimized inclusion complex adalah }}$ nilai energi kompleks inklusi hasil optimasi geometri dengan metode kuantum semiempirik PM3, $E_{\text {optimized host }}$ adalah nilai energi molekul host hasil optimasi geometri dengan metode kuantum semiempirik PM3, dan $E_{\text {optimized guest }}$ adalah nilai energi molekul guest hasil optimasi geometri dengan metode kuantum semiempirik PM3. Dalam penelitian ini, perhitungan dengan melibatkan pelarut air secara implisit juga dilakukan untuk memprediksi kelarutan hidroksiklorokuin sebelum dan setelah membentuk kompleks inklusi dengan $\beta$ siklodekstrin.

\section{Hasil dan Pembahasan}

Kompleks inklusi antara $\beta$-siklodekstrin dan hidroksiklorokuin memiliki nilai energi ikat antarmolekul sebesar 4,792 $\mathrm{kkal} / \mathrm{mol}$ dan nilai disosiasi konstan sebesar 0,307 mM dari hasil pemodelan penambatan molekul. Nilai positif energi ikat antarmolekul ini menunjukkan bahwa energi yang dibutuhkan untuk memutus ikatan antamolekul antara $\beta$-siklodekstrin dan hidroksiklorokuin adalah 4,792 kkal/mol dan kompleks inklusi yang terbentuk bersifat stabil. Gambar 1 memperlihatkan kompleks inklusi $\beta$ siklodekstrin dan hidroksiklorokuin hasil dari pemodelan penambatan molekul, dimana bagian organik yang mengandung atom $\mathrm{Cl}$ pada hidroksiklorokuin terletak pada rongga $\beta$-siklodekstrin dengan diameter yang lebih besar. Struktur molekul kompleks inklusi dengan energi ikat antarmolekul paling positif dari hasil penambatan molekul, selanjutnya dihitung menggunakan metode 
Ivansyah, dkk. Akta Kimia Indonesia 5(2), 2020, 127-140

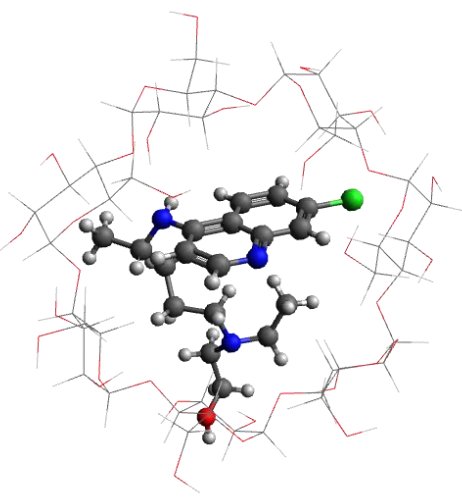

(a)

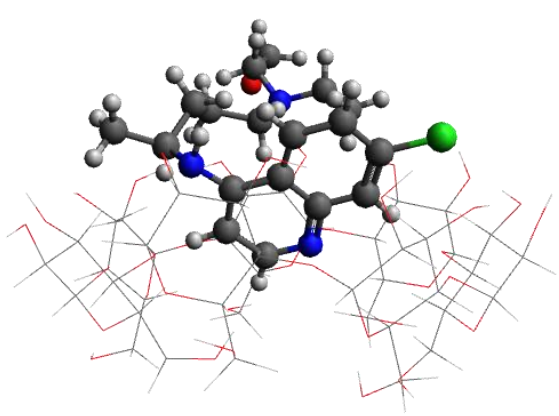

(b)

Gambar 1 Struktur molekul kompleks inklusi terbaik antara $\beta$ siklodekstrin dan hidroksikloroquin dari pemodelan penambatan molekul dengan nilai energi ikat antarmolekul paling positif: (a) tampak atas, (b) tampak samping

kuantum semiempiris untuk memperbaiki nilai energi ikat antarmolekul agar lebih akurat.

Struktur $\beta$-siklodekstrin yang kaku digunakan pada pemodelan penambatan molekul ini sehingga hasil pemodelan ini memiliki tingkat akurasi yang relatif rendah, terutama untuk nilai energi ikat antarmolekul. Oleh karena itu, untuk mencapai tingkat akurasi yang lebih baik, sangat penting untuk mengoptimasi kembali struktur hasil penambatan molekul dengan metode/teori yang lebih tinggi. Dalam penelitian ini, telah digunakan metode kuantum semiempiris PM3 untuk mengoptimasi kompleks inklusi hasil pemodelan penambatan molekul, dimana 
Ivansyah, dkk. Akta Kimia Indonesia 5(2), 2020, 127-140

relaksasi dilakukan pada $\beta$-siklodekstrin dan hidroksiklorokuin.

Sejak tahun 1995, sebagian besar penelitian berfokus pada studi kompleks inklusi menggunakan $\beta$-siklodekstrin sebagai molekul host dengan metode kuantum semiempiris AM1 dan PM3 untuk mendapatkan sifat elektronik dan beberapa informasi mengenai geometri kompleks inklusi. Hasil yang diperoleh peneliti sebelumnya menunjukkan bahwa metode PM3 memiliki akurasi perhitungan yang lebih baik jika dibandingkan dengan metode AM1. Pada tahun 2000, telah dilakukan beberapa studi perbandingan metode PM3 dan AM1 pada beberapa model senyawa, salah satunya adalah hidroksietil eter dan $\alpha$ - $(1,4)$ glukobiosa. Berdasarkan hasil tersebut, dapat disimpulkan bahwa PM3 memiliki akurasi perhitungan yang lebih baik daripada metode AM1, terutama pada perhitungan yang melibatkan molekul siklodekstrin karena metode kuantum semiempiris PM3 dapat memprediksi ikatan hidrogen $\mathrm{OH}$--- $\mathrm{O}$ lebih baik jika dibandingkan dengan metode AM1. Dalam penelitian ini, struktur molekul kompleks inklusi yang ditunjukkan pada Gambar 1 dioptimasi ulang menggunakan metode kuantum semiempirik PM3 dalam kondisi vakum dan dengan adanya pelarut

air. Nilai energi ikat antarmolekul $(\Delta \mathrm{E})$ kompleks inklusi antara $\beta$-siklodekstrin dan hidroksiklorokuin adalah -13,214 kkal/mol dan $-7,894 \mathrm{kkal} / \mathrm{mol}$ yang diperoleh dari perhitungan kuantum semiempirik PM3 dalam kondisi vakum dan dengan adanya pelarut air, secara berturut-turut. Nilai energi ikat antarmolekul yang negatif ini mengindikasikan bahwa kompleks inklusi antara $\beta$-siklodekstrin dan hidroksiklorokuin bersifat stabil. Semakin negatif nilainya, semakin stabil pembentukan kompleks inklusi tersebut. Pada penelitian ini juga dihitung nilai energi ikat antarmolekul menggunakan metode kuantum semiempirik PM3 dan metode PCM pada kondisi yang melibatkan adanya pelarut air. $\beta$ siklodekstrin dan hidroksiklorokuin membentuk kompleks inklusi yang stabil di dalam air dengan nilai $\Delta \mathrm{E}$ pelarutan kompleks inklusi sebesar $-49,75 \mathrm{kkal} / \mathrm{mol}$ yang dihitung dengan menggunakan persamaan yang dinyatakan oleh persamaan (1). Gambar 2 memperlihatkan diagram skema dari pembentukan kompleks inklusi antara $\beta$-siklodekstrin dan hidroksiklorokuin.

$$
\begin{aligned}
& \Delta E=E_{\text {molecule in solution phase }}- \\
& E_{\text {molecule in gas phase }}
\end{aligned}
$$

(2) 
Ivansyah, dkk. Akta Kimia Indonesia 5(2), 2020, 127-140

Gambar 2 memperlihatkan diagram skema pelarutan kompleks inklusi $\beta$-siklodekstrin dan hidroksiklorokuin, dimana $E_{1}, E_{2}, E_{3}, E_{4}$, $E_{5}, E_{6}$, secara berturut-turut adalah energi hidroksiklorokuin dalam vakum atau gas, energi $\beta$-siklodekstrin dalam vakum atau gas, energi kompleks inklusi antara $\beta$ siklodekstrin dan hidroksiklorokuin dalam vakum atau gas, energi hidroksiklorokuin dalam kondisi pelarutan implisit dengan pelarut air, energi $\beta$-siklodekstrin dalam kondisi pelarutan implisit dengan pelarut air, energi kompleks inklusi antara $\beta$ siklodekstrin dan hidroksiklorokuin dalam kondisi pelarutan implisit dengan pelarut air. Sedangkan, $\Delta \mathrm{E}_{1}, \Delta \mathrm{E}_{2}, \Delta \mathrm{E}_{3}, \Delta \mathrm{E}_{4}, \Delta \mathrm{E}_{5}$ secara berturut-turut adalah energi pembentukan kompleks inklusi dalam kondisi vakum atau fasa gas, atau dapat disebut sebagai energi ikat antarmolekul antara $\beta$-siklodekstrin dan hidroksiklorokuin dalam vakum atau dalam fasa gas yang mana $\Delta E_{1}=E_{3}-\left(E_{1}+E_{2}\right)$, energi pelarutan hidroksiklorokuin dalam pelarut air yang mana $\Delta E_{2}=E_{4}-E_{1}$, energi pelarutan $\beta$-siklodekstrin dalam pelarut air dimana $\Delta \mathrm{E}_{3}$ $=E_{5}-E_{2}$, energi pembentukan kompleks inklusi dalam kondisi vakum atau fasa gas atau dapat kita sebut sebagai energi ikat antarmolekul antara $\beta$-siklodekstrin dan hidroksiklorokuin dalam pelarut air yang mana $\Delta \mathrm{E} 4=\mathrm{E} 6-(\mathrm{E} 4+\mathrm{E} 5)$, energi pelarutan kompleks inklusi $\beta$-siklodekstrin dan hidroksiklorokuin dalam pelarut air yang mana $\Delta \mathrm{E} 5=\mathrm{E} 6-\mathrm{E} 3$.

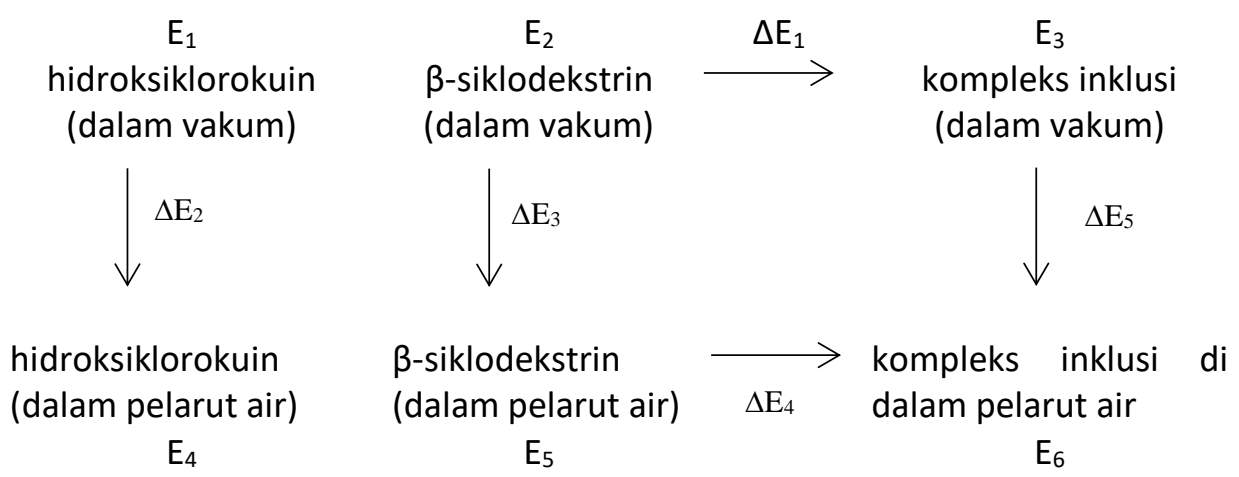

Gambar 2 Diagram skema pelarutan kompleks inklusi 
Ivansyah, dkk. Akta Kimia Indonesia 5(2), 2020, 127-140

Berdasarkan persamaan (2) dan Gambar 2, nilai $\Delta \mathrm{H}_{\text {solvasi }}$ dan $\Delta \mathrm{G}_{\text {solvasi }}$ kompleks inklusi antara $\beta$-siklodekstrin dan hidroksiklorokuin, secara berturut-turut adalah sebesar $-31,816$ $\mathrm{kkal} / \mathrm{mol}$ dan $-34.447 \mathrm{kkal} / \mathrm{mol}$. Nilai negatif ini mengindikasikan bahwa pembentukan kompleks inklusi antara $\beta$-siklodekstrin dan hidroksiklorokuin dalam pelarut air bersifat eksotermik dan spontan. Gambar 3 memperlihatkan grafik $\Delta \mathrm{E}_{\text {solvasi, }} \Delta \mathrm{H}_{\text {solvasi, }}$ dan $\Delta G_{\text {solvasi }}$ hidroksikloroquin, $\beta$-siklodekstrin, dan kompleks inklusi antara $\beta$-siklodekstrin dan hidroksiklorokuin.

Gambar 3 memperlihatkan bahwa kompleks inklusi antara $\beta$-siklodekstrin dan hidroksiklorokuin memiliki nilai $\Delta \mathrm{E}_{\text {solvasi, }}$ $\Delta H_{\text {solvasi, }}$ dan $\Delta \mathrm{G}_{\text {solvasi }}$ yang lebih negatif jika dibandingkan dengan nilai $\Delta \mathrm{E}_{\text {solvasi, }} \Delta \mathrm{H}_{\text {solvasi, }}$ dan $\Delta \mathrm{G}_{\text {solvasi }}$ dari masing-masing hidroksiklorokuin dan $\beta$-siklodekstrin sebelum membentuk kompleks inklusi. Artinya, kelarutan hidroksiklorokuin dan kelarutan $\beta$-siklodekstrin dalam air dapat ditingkatkan dengan membentuk kompleks inklusi di antara keduanya.

Gambar 4 memperlihatkan struktur kompleks inklusi antara $\beta$-siklodekstrin dan hidroksiklorokuin yang teroptimasi dari hasil perhitungan dengan metode kuantum semiempirik PM3 dalam kondisi vakum dan dengan adanya pelarut air. Hidroksiklorokuin dan $\beta$-siklodekstrin membentuk kompleks inklusi yang stabil dengan gugus fungsi organik yang mengandung atom $\mathrm{Cl}$ terletak di dalam rongga $\beta$-siklodekstrin yang berukuran lebih besar.

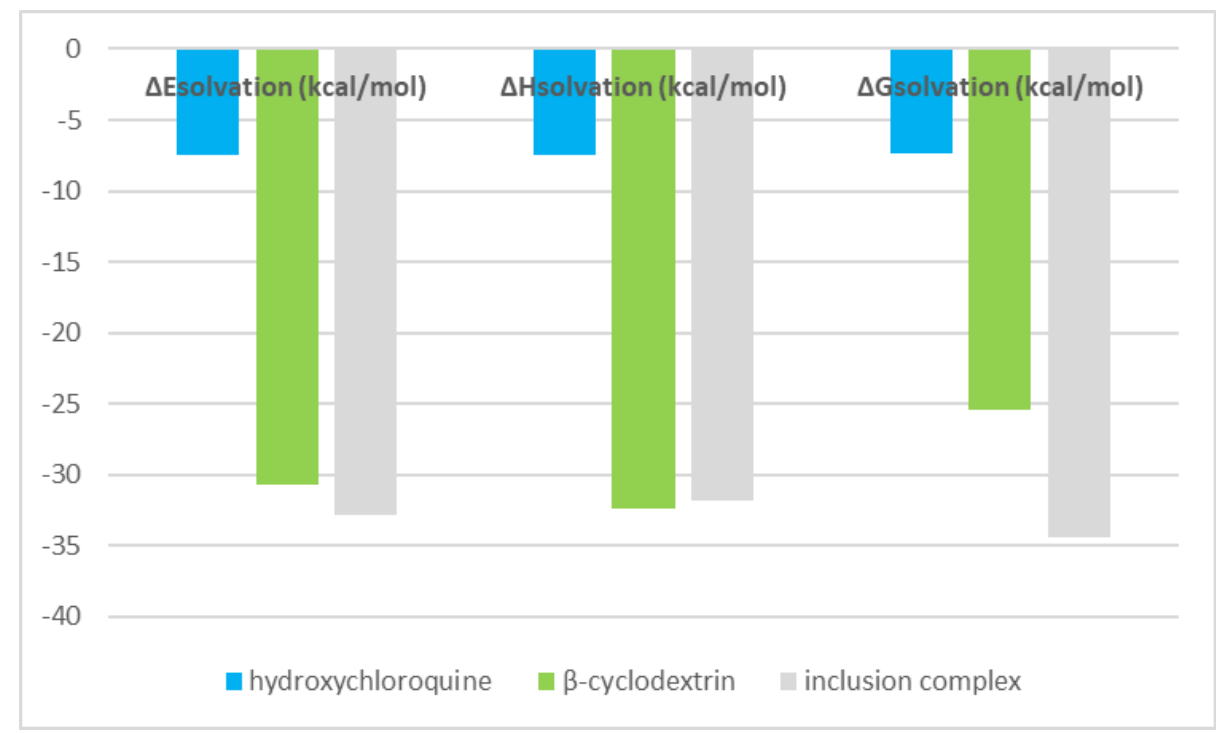

Gambar $3 \Delta \mathrm{E}_{\text {solvasi, }} \Delta \mathrm{H}_{\text {solvasi, }}$ dan $\Delta \mathrm{G}_{\text {solvasi }}$ hidroksikloroquin, $\beta$-siklodekstrin, dan kompleks inklusi antara $\beta$ siklodekstrin dan hidroksikloroquin 
Kelarutan kompleks inklusi juga dapat dinyatakan sebagai partisi dari kompleks inklusi antara pelarut organik (1-oktanol) dan pelarut air. Partisi ini dapat dinyatakan dengan persamaan (2).

$$
\begin{aligned}
& -R T \ln P_{o / w}= \\
& G_{\text {inclusion complex in } 1-o c t a n o l}- \\
& G_{\text {inclusion complex in water }}
\end{aligned}
$$

$$
P_{o / w}=\frac{[\text { inclusion complex }]_{1-\text { octanol }}}{[\text { inclusion complex }]_{\text {water }}}
$$

Semakin kecil nilai $\mathrm{P}_{\mathrm{o} / \mathrm{w}}$, kompleks inklusi $\ln P_{o / w}=$ $-\frac{G_{\text {inclusion complex in 1-octanol }}-G_{\text {inclusion complex in water }}}{R T}$ akan semakin mudah larut dalam air, begitu pula sebaliknya. Perhitungan $\mathrm{P}_{\mathrm{o} / \mathrm{w}}$ dapat diturunkan dari persamaan reaksi kesetimbangan (3) berikut, kemudian akan diperoleh $\mathrm{P}_{\mathrm{o} / \mathrm{w}}$ seperti yang dinyatakan oleh persamaan (8).

kompleks inklusi $_{(\text {dalam pelarut air })} \rightleftharpoons$ kompleks inklusi $i_{(\text {dalam pelarut 1-oktanol) }}$

$\Delta G_{1-o c t a n o l} /$ water $=$ $G_{\text {inclusion complex in 1-octanol }}$ $G_{\text {inclusion complex in water }}$

$-R T \ln \frac{\left[{\text { inclusion complex }]_{1-\text { octanol }}}_{\text {inclusion complex }]_{\text {water }}}\right.}{[\text { in }}=$ $P_{o / w}=$
$e^{-\left(\frac{G_{\text {inclusion complex in } 1-o c t a n o l}-G_{\text {inclusion complex in water }}}{R T}\right)}$

Dari nilai $\mathrm{P}_{\mathrm{o} / \mathrm{w}}$ yang diperoleh dari perhitungan dengan metode kuantum semiempirik PM3, ditemukan bahwa kelarutan hidroksiklorokuin dan $\beta$ siklodekstrin dapat ditingkatkan dengan membentuk kompleks inklusi di antara keduanya dengan nilai $\mathrm{P}_{\mathrm{o} / \mathrm{w}}$ secara berturutturut untuk hidroksiklorokuin, $\beta$ siklodekstrin, kompleks inklusi antara $\beta$ siklodekstrin dan hidroksiklorokuin adalah $G_{\text {inclusion complex in 1-octanol }}$ $G_{\text {inclusion complex in water }}$ 


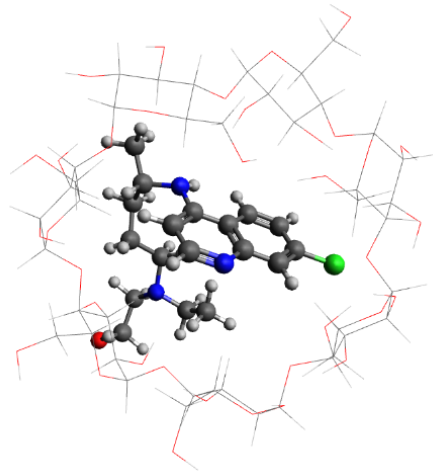

(a)

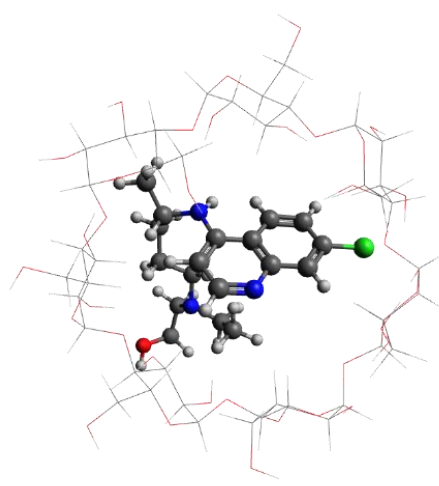

(c)

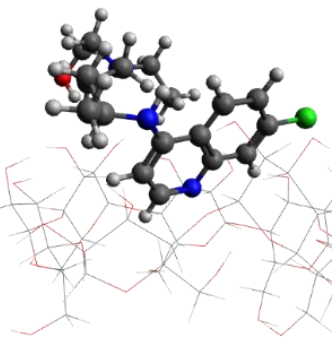

(b)

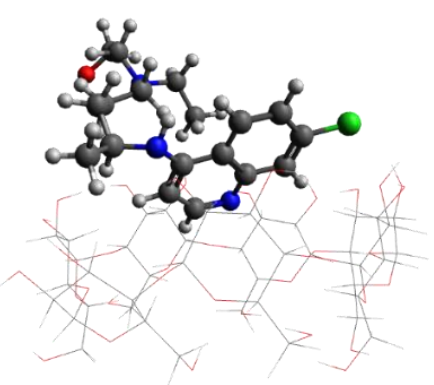

(d)

Gambar 4 Struktur teroptimasi dari kompleks inklusi $\beta$-siklodekstrin dan hidroksiklorokuin yang dihitung dengan metode kuantum semiempirik PM3 dalam kondisi vakum (a) tampak atas, (b) tampak samping, dan kondisi pelarutan implisit dengan pelarut air (c) tampak atas, (d) tampak samping

\section{Kesimpulan}

Dari penelitian ini didapatkan bahwa hidroksiklorokuin membentuk kompleks inklusi yang stabil dengan $\beta$-siklodekstrin dengan nilai energi ikat antarmolekul sebesar 4,792 $\mathrm{kkal} / \mathrm{mol}$ yang diperoleh dari pemodelan penambatan molekul, -13,214 $\mathrm{kkal} / \mathrm{mol}$ yang diperoleh dari perhitungan kuantum semiempirik PM3 dalam kondisi vakum, dan $-7,894 \mathrm{kkal} / \mathrm{mol}$ diperoleh dari perhitungan kuantum semiempirik PM3 dalam kondisi dengan adanya pelarut air. Kelarutan hidroksiklorokuin dalam pelarut air dapat ditingkatkan dengan membentuk kompleks inklusi dengan $\beta$-siklodekstrin, seperti yang diperlihatkan oleh Gambar 3. 
Ivansyah, dkk. Akta Kimia Indonesia 5(2), 2020, 127-140

Namun, hasil ini masih harus dikonfirmasi dengan teori yang lebih tinggi, seperti metode DFT, untuk mendapatkan hasil kalkulasi yang lebih akurat.

\section{Ucapan Terimakasih}

Penelitian ini telah didanai oleh Program Hibah Penelitian DIKTI pada tahun 2020 dengan nomor kontrak 2 / AMD / E1 / KP.PTNBH / 2020, yang diberikan oleh Pemerintah Indonesia melalui Kementerian Pendidikan dan Kebudayaan Republik Indonesia. Penulis juga mengucapkan terima kasih kepada Dr. Enung Siti Nurhidayah dan Suci Zulaikha Hildayani, M.Si. bantuannya dalam mengumpulkan dan menganalisis data hasil penelitian.

\section{Daftar Pustaka}

[1] V. R. Sinha, R. Anitha, S. Ghosh, A. Nanda, and R. Kumria, "Complexation of celecoxib with $\beta$-cyclodextrin: Characterization of the interaction in solution and in solid state," J. Pharm. Sci., vol. 94, no. 3, pp. 676-687, Mar. 2005.

[2] C. Anselmi et al., "Analytical characterization of a ferulic acid $/ \mathrm{Y}^{-}$ cyclodextrin inclusion complex," J.
Pharm. Biomed. Anal., vol. 40, no. 4, pp. 875-881, Mar. 2006.

[3] K. L. Yap, X. Liu, J. C. Thenmozhiyal, and P. C. Ho, "Characterization of the 13-cis-retinoic acid/cyclodextrin inclusion complexes by phase solubility, photostability, physicochemical and computational analysis," Eur. J. Pharm. Sci., vol. 25, no. 1, pp. 49-56, May 2005.

[4] T. Irie and K. Uekama, "Pharmaceutical applications of cyclodextrins. III. Toxicological issues and safety evaluation," Journal of Pharmaceutical Sciences, vol. 86, no. 2. John Wiley and Sons Inc., pp. 147162, Feb. 01, 1997.

[5] M. E. Brewster and T. Loftsson, "Cyclodextrins as pharmaceutical solubilizers," Advanced Drug Delivery Reviews, vol. 59, no. 7. Elsevier, pp. 645-666, Jul. 30, 2007.

[6] R. L. Carrier, L. A. Miller, and I. Ahmed, "The utility of cyclodextrins for enhancing oral bioavailability," Journal of Controlled Release, vol. 123, no. 2. Elsevier, pp. 78-99, Nov. 06, 2007.

[7] K. Uekama, F. Hirayama, and T. Irie, "Cyclodextrin drug carrier systems," 
Ivansyah, dkk. Akta Kimia Indonesia 5(2), 2020, 127-140

Chem. Rev., vol. 98, no. 5, pp. 20452076, 1998.

[8] F. Hirayama and K. Uekama, "Cyclodextrin-based controlled drug release system," Advanced Drug Delivery Reviews, vol. 36, no. 1. Elsevier Science Publishers B.V., pp. 125-141, Mar. 01, 1999.

[9] M. E. Davis and M. E. Brewster, "Cyclodextrin-based pharmaceutics: Past, present and future," Nature Reviews Drug Discovery, vol. 3, no. 12. pp. 1023-1035, Dec. 2004.

[10] T. Loftsson and M. E. Brewster, "Pharmaceutical applications of cyclodextrins: Effects on drug permeation through biological membranes," J. Pharm. Pharmacol., vol. 63, no. 9, pp. 11191135, Sep. 2011.

[11]

N. Grancher et al., "Improved antiviral activity in vitro of ribavirin against measles virus after complexation with cyclodextrins," Antiviral Res., vol. 62, no. 3, pp. 135137, Jun. 2004 C. Nicolazzi, V. Venard, A. Le Faou, and C. Finance, "In vitro antiviral efficacy of the ganciclovir complexed with $\beta$-cyclodextrin on human cytomegalovirus clinical strains," Antiviral Res., vol. 54, no. 2, pp. 121-127, May 2002

[13]

F. Carrouel et al., "COVID-19:

A Recommendation to Examine the Effect of Mouthrinses with $\beta$ Cyclodextrin Combined with Citrox in Preventing Infection and Progression," J. Clin. Med., vol. 9, no. 4, p. 1126, Apr. 2020

C. Lonie, T. Vandermeerschd, E. Zurek, and G. R. Hutchison, "Avogadro: An advanced semantic chemical editor, visualization, and analysis platform," J. Cheminform., vol. 4, no. 8, p. 17, Aug. 2012.

[15]

E. Krieger and G. Vriend, "New ways to boost molecular dynamics simulations," J. Comput. Chem., vol. 36, no. 13, pp. 996-1007, May 2015.

[16] Gaussian 09, Revision D.01, M. J. Frisch, G. W. Trucks, H. B. Schlegel, G. E. Scuseria, M. A. Robb, J. R. Cheeseman, G. Scalmani, V. Barone, G. A. Petersson, H. Nakatsuji, X. Li, M. Caricato, A. Marenich, J. Bloino, B. G. Janesko, R. Gomperts, B. Mennucci, H. P. Hratchian, J. V. Ortiz, 
Ivansyah, dkk. Akta Kimia Indonesia 5(2), 2020, 127-140

A. F. Izmaylov, J. L. Sonnenberg, D. Williams-Young, F. Ding, F. Lipparini, F. Egidi, J. Goings, B. Peng, A. Petrone, T. Henderson, D. Ranasinghe, V. G. Zakrzewski, J. Gao, N. Rega, G. Zheng, W. Liang, M. Hada, M. Ehara, K. Toyota, R. Fukuda, J. Hasegawa, M. Ishida, T. Nakajima, Y. Honda, O. Kitao, H. Nakai, T. Vreven, K. Throssell, J. A. Montgomery, Jr., J. E. Peralta, F. Ogliaro, M. Bearpark, J. J. Heyd, E. Brothers, K. N. Kudin, V. N. Staroverov, T. Keith, R. Kobayashi, J. Normand, K. Raghavachari, A. Rendell, J. C. Burant, S. S. Iyengar, J. Tomasi, M. Cossi, J. M. Millam, M. Klene, C. Adamo, R. Cammi, J. W. Ochterski, R. L. Martin, K. Morokuma, O. Farkas, J. B. Foresman, and D. J. Fox, Gaussian, Inc., Wallingford CT, 2016.

S. Setiadji, C. D. D. Sundari, M.

A. Ramdhani, A. B. K. Umam, and A. L. Ivansyah, "Theoretical Investigation of Inclusion Complex between Omeprazole Enantiomers and Carboxymethyl- $\beta$-Cyclodextrin," in IOP Conference Series: Materials Science and Engineering, Jan. 2018, vol. 288 , no. 1 , p. 012138.
A. L. Ivansyah, E. S. Nurhidayah, C. D. D. Sundari, M. A. Martoprawiro, and B. Buchari, "Computational study of inclusion complex between Omeprazole enantiomer and $\beta$-Cyclodextrin: NBO and RDG analysis," in Journal of Physics: Conference Series, Dec. 2019, vol. 1402 , no. 5 .

S. Setiadji, C. D. D. Sundari, B. W. Nuryadin, H. Zayyinunnisya, R. Cahyandari, and A. L. Ivansyah, "Computational Study of Inclusion Complexes between Omeprazole Enantiomer with Hydroxypropyl- $\beta$ Cyclodextrin," in Journal of Physics: Conference Series, Sep. 2018, vol. 1090, no. 1.

[20]

S. Setiadji, C. D. D. Sundari, M.

A. Ramdhani, A. B. K. Umam, and A. L. Ivansyah, "Theoretical Investigation of Inclusion Complex between Omeprazole Enantiomers and Carboxymethyl- $\beta$-Cyclodextrin," in IOP Conference Series: Materials Science and Engineering, Jan. 2018, vol. 288 , no. 1 .

A. L. Ivansyah, M. A. Martoprawiro, and Buchari, "Computational modeling of 
Ivansyah, dkk. Akta Kimia Indonesia 5(2), 2020, 127-140

inclusion complex of r/s-omeprazole with $\beta$-cyclodextrin using oniom2 method," in Journal of Physics: Conference Series, Mar. 2017, vol. 812 , no. 1 .

[22] C. Betzel, W. Saenger, B. E. Hingerty, and G. M. Brown, "Circular and Flip-Flop Hydrogen Bonding in $\beta$ Cyclodextrin Undecahydrate: A Neutron Diffraction Study," J. Am. Chem. Soc., vol. 106, no. 24, pp. 7545-7557, Nov. 1984.

[23] https://www.ccdc.cam.ac.uk/ structures/Search?Ccdcid=BUVSEQ02 \&DatabaseToSearch=Published.

Accessed November 10, 2020.

[24] I. Andreadelis et al., "Charting the structural and thermodynamic determinants in phenolic acid natural product $\quad-\quad$ cyclodextrin encapsulations," J. Biomol. Struct. Dyn., pp. 1-17, Apr. 2020. the interactions and bioactivity of quercetin-(2-hydroxypropyl)- $\beta$ cyclodextrin complex," Int. J. Pharm., vol. 511, no. 1, pp. 303-311, Sep. 2016.

[26] D. Ntountaniotis et al., "HostGuest Interactions between
Candesartan and Its Prodrug Candesartan Cilexetil in Complex with 2-Hydroxypropyl- $\beta$-cyclodextrin: On the Biological Potency for Angiotensin II Antagonism," Mol. Pharm., vol. 16, no. 3, pp. 12551271, Mar. 2019.

[27] T. F. Kellici et al., "Investigation of the interactions of silibinin with 2-hydroxypropyl- $\beta$ cyclodextrin through biophysical techniques and computational methods," Mol. Pharm., vol. 12, no. 3, pp. 954-965, Mar. 2015.

G. G. Kordopati et al., "A novel synthetic luteinizing hormonereleasing hormone (LHRH) analogue coupled with modified $\beta$ cyclodextrin: Insight into its intramolecular interactions," Biochim. Biophys. Acta - Gen. Subj., vol. 1850 , no. 1 , pp. 159-168, Jan. 2015

[29]

G. Leonis et al., "Antihypertensive activity and molecular interactions of irbesartan in complex with 2-hydroxypropyl- $\beta$ cyclodextrin," Chem. Biol. Drug Des. vol. 96, no. 1, pp. 668-683, Jul. 2020. 